\title{
Treatment of grass pollen allergy: focus on a standardized grass allergen extract - Grazax ${ }^{\circledR}$
}

\author{
Moisés Calderón' \\ Tove Brandt ${ }^{2}$ \\ 'Section of Allergy and Clinical \\ Immunology, Royal Brompton \\ Hospital, Imperial College, NHLI, \\ London, UK; ${ }^{2}$ Group Clinical \\ Development, ALK-Abelló A/S, \\ Hørsholm, Denmark
}

\begin{abstract}
Immunotherapy is the only treatment for allergy that has the potential to alter the natural course of the disease. Sublingual immunotherapy (SLIT) for grass pollen-induced rhino-conjunctivitis has been developed to make immunotherapy available to a broader group of allergic patients. In the largest clinical programme ever conducted with allergen-specific immunotherapy, over 1,700 adults and 260 children have been exposed to Grazax ${ }^{\circledR}$. Grazax is formulated as an oral lyophilisate (tablet) for sublingual administration, containing 75,000 SQ-T standardized allergen extract of grass pollen from Phleum pratense. Grazax is indicated for treatment of grass pollen-induced rhinitis and conjunctivitis in adult patients with clinically relevant symptoms and diagnosed with a positive skin prick test and/or specific IgE test to grass pollen. In phase I trials doses from 2,500 to 1,000,000 SQ-T were tested. All doses were well tolerated and 75,000 SQ-T, with approximately $15 \mu \mathrm{g}$ major allergen protein, was chosen as the optimal dose. Three phase III trials are ongoing, one being a long-term trial. Results from GT-08 trial first and second treatment years showed a reduction of 30\% and 36\%, respectively, in daily rhino-conjunctivitis symptom scores and a reduction of $38 \%$ and $46 \%$ of daily rhinoconjunctivitis medication scores compared with placebo over the entire grass pollen season. Subjects treated with Grazax also had an increased number of well days and improved quality of life, and more subjects experienced excellent rhino-conjunctivitis control. The most common adverse events related to Grazax are local reactions, such as pruritus, edema mouth, ear pruritus, throat irritation, and sneezing. We conclude that Grazax is efficacious and safe for treatment of rhino-conjunctivitis due to grass pollen allergy.
\end{abstract}

Keywords: sublingual immonotherapy, grass pollen allergy, rhinoconjunctivitis, immunotherapy, tablet

\section{Introduction}

Overall, it is estimated that one quarter of the European population suffers from respiratory allergies such as allergic rhinitis, and the prevalence is increasing, although it varies among countries (Linneberg et al 2000; Dahl et al 2004). Grass pollen is the most common cause of respiratory allergies, and is associated with more than $50 \%$ of allergic rhinitis cases (Bauchau and Durham 2004). Allergic rhinitis can leave a significant burden of residual symptoms even among those receiving optimal symptomatic treatment (White et al 1998). Only allergen-specific immunotherapy (SIT) targets the underlying allergic disease, having the potential to produce long-term remission and to prevent the development of new sensitizations and asthma. SIT increases the tolerability to a specific allergen, thereby reducing the allergic symptoms and the consumption of symptomatic treatment.

Grazax $^{\circledR}$ (ALK-Abello A/S, Hoersholm, Denmark) is the first registered and marketed allergy tablet (oral lyophilisate) to treat the underlying cause of grass pollen-induced rhinoconjunctivitis in adult subjects. In order to ensure treatment of subjects with the correct indication, Grazax should be prescribed only by doctors with special knowledge and experience in treating allergic diseases. Grazax is a home-based 
treatment and requires fewer visits to the doctor compared with traditional subcutaneous SIT. Visits are greatly reduced from 39 with subcutaneous SIT to about 6 visits with Grazax, contributing to a more cost-effective treatment compared with subcutaneous treatment under the conviction that the treatment is as effective.

\section{Doses and substance}

The recommended daily dose for adults is one tablet/ oral lyophilisate (75,000 SQ-T/2,800 BAU), containing approximately $15 \mu \mathrm{g}$ major allergen Phleum pratense (Calderon et al 2007). Subjects should start treatment as a minimum 2 months prior to the grass pollen season without any up-dosing period (Calderon et al 2005). Grazax contains the same active pharmaceutical ingredient (API) as Alutard $\mathrm{SQ}^{\circledR}$ grass pollen, which has been used for more than 20 years as a subcutaneous SIT. The API is a standardized allergen extract from Phleum pratense grass pollen. It has been shown to have extensive cross-reactivity of allergenic components of grass pollens from different species (Andersson and Lidholm 2003; Weber 2005).

\section{Pharmacokinetics}

As the active molecules of the allergens in Grazax are polypeptides and proteins, it is expected that these are hydrolyzed to amino acids and small polypeptides in the lumen of the gastrointestinal tract and in the local tissues. There is no evidence to suggest that the allergens present in Grazax are absorbed into the vascular system to any significant extent (Senel et al 2001; Bagnasco et al 2003, 2005; Moingeon et al 2006). Consequently, no pharmacokinetics trials have been conducted.

\section{Mechanism of action - pharmacodynamics in humans}

The mechanism of SIT is very complex and the exact mechanism of action is still not fully understood. However, it is widely acknowledged that subcutaneous and sublingual SIT acts as a modifier of the immune system. The mechanism is a combination of altered regulation of IgE syntheses and induction of IgE-blocking antibodies, with the capacity to competitively inhibit the interaction between allergen and IgE. Further effects include a shift from Th2 to regulatory T-cells and inhibition of facilitating antigen presentation of the specific T-cells. For Grazax it is documented that the amount of antibodies in serum is dependent on doses, and Grazax and Alutard SQ Phleum pratense give a clear and qualitatively similar antibody response (Malling et al 2006).

\section{Clinical trials}

The clinical development program for Grazax was initiated to investigate the optimal dosing regimen as well as the tolerability, safety, and efficacy profile of Grazax.

Five phase I trials (GT-01, GT-03, GT-04, GT-09 and GT-11) assessed the tolerability. Doses from 2,500 to $1,000,000 \mathrm{SQ}-\mathrm{T}$ were tested in subjects with grass pollen allergy without any up-dosing period for any of the doses. The highest dose tested was 13 times higher than the approved dose (75,000 SQ-T). Even the high doses of Grazax were well tolerated, primarily with local adverse events, and no serious or systemic adverse events were reported (Kleine-Tebbe et al 2006). Furthermore, clinical safety and efficacy were investigated in a phase II/III trial (GT-02), one phase II trial (GT-07) and one phase III efficacy trial (GT-08). Long-term efficacy and safety were investigated in an extension of the GT-08 trial, and interim results after 1 and 2 years have been published (Dahl et al 2006a, 2008). The effect of a compliance device on treatment compliance was investigated in a phase IIIb trial (GT-10 trial). Three phase III trials are ongoing, though the trial periods for GT-12 and GT-14 are completed.

The number of subjects exposed to Grazax in the completed clinical trials is 1,619; in addition 860 adults are exposed in the on-going GT-08 extension and GT-14 study. A number of subjects are also exposed in relation to ongoing phase IV activities. The patient exposure on the market is, as of December 2007, 6,936 treatment years. Table 1 shows an overview of the completed and ongoing trials on Grazax.

Based on results from the first year of GT-08, Grazax was approved in 27 European countries for treatment of grass pollen-induced rhinitis and conjunctivitis in adults with clinically relevant symptoms and diagnosed with a positive skin prick test and/or specific IgE test to grass pollen.

In GT-08, trial treatment was initiated at least 16 weeks before the anticipated start of the grass pollen season, and the efficacy was measured according to the newest recommendation from the World Allergy Organisation (Canonica et al 2007). Six allergic symptoms were rated daily (runny nose, blocked nose, sneezing, itchy nose, gritty feeling/red/itchy eyes, and watery eyes). Subjects treated with Grazax had a numerically lower symptom score than the placebo group. This was evident in both nose and eye symptoms during the entire grass pollen season. During 


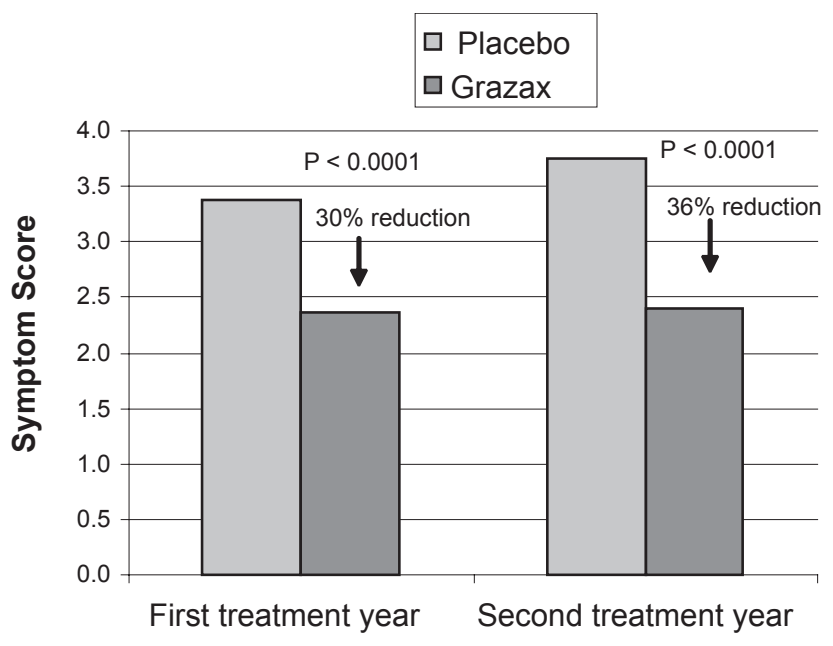

Symptom score

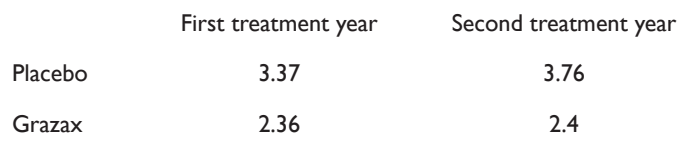

Figure I Symptom score from the first and second treatment year.

the first and second treatment years Grazax reduced mean daily rhino-conjunctivitis symptom score by $30 \%$ and $36 \%$, respectively (Figure 1), and mean daily rhino-conjunctivitis medication score by $38 \%$ and $46 \%$, respectively, compared with placebo over the entire grass pollen season (Figure 2). The differences in symptom and medication score differed significantly $(p<0.0001)$ from the placebo group. These results confirmed results obtained from earlier trials with Grazax (Durham et al 2006; Dahl et al 2006b), and are consistent with the efficacy results reported for subcutaneous SIT (Frew et al 2006).

Subjects in the Grazax group also reported an increased number of well days during the grass pollen season (days with few symptoms and no need for rescue medication), improved quality of life (assessed by Juniper's Rhino-conjunctivitis Quality of Life Questionnaire) (Junier and Guyatt 1991), and more subjects experienced excellent rhino-conjunctivitis control compared with the placebo group (Durham et al 2007; Rak et al 2007). These results support the contention that reductions in rhino-conjunctivitis medication and symptoms score translate into important benefits for the subjects and therefore can be considered clinically relevant.

In addition, $82 \%$ and $69 \%$ of the subjects treated with Grazax felt much better or better compared with previous grass pollen season during the first and second year. For comparison $54 \%$ of the subjects (first grass pollen season) and $57 \%$ of subjects (second grass pollen season)

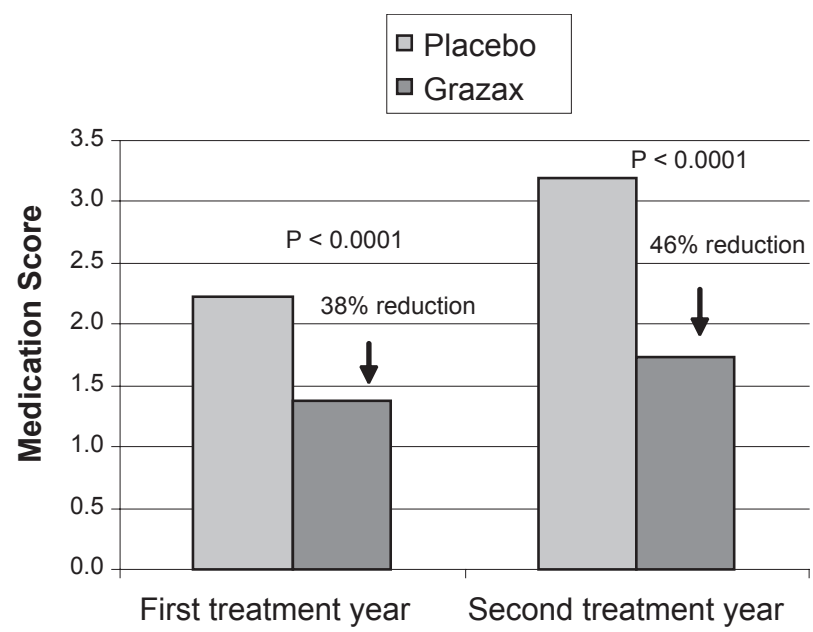

Medication score

$\begin{array}{ccc} & \text { First treatment year } & \text { Second treatment year } \\ \text { Placebo } & 2.23 & 3.19 \\ \text { Grazax } & 1.38 & 1.74\end{array}$

Figure $\mathbf{2}$ Medication score from the first and second treatment year.

in the placebo group felt much better or better compared with previous grass pollen season. The high placebo effect can partly be explained by the fact that the placebo group used more medication than the Grazax group (Dahl et al 2006a).

\section{Safety}

Even though the reported efficacy of subcutaneous and sublingual immunotherapy is of similar magnitude, the treatment regimen and the safety profiles are completely different. The expected adverse events (AE) during subcutaneous immunotherapy are largely of two types, local reactions at the injections site and systemic reactions characterized by generalized signs and/or symptoms occurring distant from the injection site. Since the injection of allergens against which a subject has IgE antibodies may induce anaphylactic shock, it is recommended that all subjects are observed for 20 or 30 minutes after each injection and the treatment should be performed only by specialists (Bousquet et al 1998). In contrast Grazax treatment is primarily characterized by frequent but local reactions, located in the mouth and throat, which mostly were mild to moderate. In the majority of the subjects these reactions started early in therapy, lasted from minutes to hours after each intake of Grazax, and tended to subside spontaneously within 1 to 7 days. The most common reported AE were oral pruritus, edema mouth, ear pruritus, throat irritation, and sneezing. Less commonly reported AE were headache, 
Table I Overview of clinical trials on Grazax ${ }^{\circledR}$

\begin{tabular}{|c|c|c|c|c|c|}
\hline & Trial ID & Phase & Trial objective/design & Doses tested SQ-T & Subjects \\
\hline \multirow[t]{10}{*}{ Completed trials } & GT-0I (I2) & I & $\begin{array}{l}\text { Single and multiple dose safety } \\
\text { trial conducted outside the } \\
\text { grass pollen season. }\end{array}$ & $\begin{array}{l}\text { 2,500; 25,000; 75,000; } \\
\text { I25,000; 375,000; placebo }\end{array}$ & $\begin{array}{l}52 \text { subjects with } \\
\text { allergy to grass pollen }\end{array}$ \\
\hline & GT-02 $(5 ; 16 ; 17)$ & $\mathrm{II} / \mathrm{III}$ & $\begin{array}{l}\text { Efficacy and safety trial. Max } \\
\text { duration of treatment: } 8 \text { weeks } \\
\text { prior to and then during the } \\
\text { grass pollen season } 2003 \text {. }\end{array}$ & $\begin{array}{l}2,500 ; 25,000 ; 75,000 ; \\
\text { placebo }\end{array}$ & $\begin{array}{l}855 \text { subjects with } \\
\text { allergy to grass pollen }\end{array}$ \\
\hline & GT-03 (I3) & 1 & $\begin{array}{l}28 \text { days multiple dose, } \\
\text { dose-escalation safety trial } \\
\text { conducted outside the grass } \\
\text { pollen season. }\end{array}$ & $\begin{array}{l}25,000 ; 75,000 ; 150,000 \\
300,000 ; 500,000 ; 750,000 ; \\
\text { I,000,000; placebo }\end{array}$ & $\begin{array}{l}84 \text { subjects with } \\
\text { allergy to grass pollen }\end{array}$ \\
\hline & GT-04 (I8) & 1 & $\begin{array}{l}28 \text { days multiple dose, } \\
\text { dose-escalation safety trial } \\
\text { conducted outside the grass } \\
\text { pollen season. }\end{array}$ & $\begin{array}{l}75,000 ; 150,000 ; 300,000 \\
500,000 ; \text { placebo }\end{array}$ & $\begin{array}{l}43 \text { subjects with } \\
\text { allergy to grass pollen } \\
\text { and mild to moderate } \\
\text { asthma }\end{array}$ \\
\hline & GT-07 $(5 ; 19)$ & $\|$ & $\begin{array}{l}\text { Efficacy and safety trial. } \\
\text { Duration of treatment: approx } \\
12 \text { weeks prior to and then } \\
\text { during the grass pollen season } \\
2004 \text {. }\end{array}$ & 75,000 placebo & $\begin{array}{l}\text { II } 4 \text { subjects with } \\
\text { allergy to grass pollen } \\
\text { and mild to moderate } \\
\text { grass pollen induced } \\
\text { asthma }\end{array}$ \\
\hline & GT-08 (Ist year) $(5 ;$ I4; I5) & III & $\begin{array}{l}\text { Efficacy and safety trial. } \\
\text { Duration of treatment: approx } \\
6 \text { months prior to and then } \\
\text { during the grass pollen season } \\
2005 \text {. }\end{array}$ & 75,000 placebo & $\begin{array}{l}634 \text { adult subjects } \\
\text { with seasonal grass } \\
\text { pollen-induced } \\
\text { rhinoconjunctivitis }\end{array}$ \\
\hline & $\begin{array}{l}\text { GT-08 (extension- } \\
\text { 2nd year) }\end{array}$ & III & $\begin{array}{l}\text { Efficacy and safety trial. } \\
\text { Duration of treatment: approx } \\
6 \text { months prior to and then } \\
\text { during the grass pollen season } \\
2006 \text {. }\end{array}$ & 75,000 placebo & $\begin{array}{l}35 \mathrm{I} \text { adult subjects } \\
\text { with seasonal grass } \\
\text { pollen-induced } \\
\text { rhinoconjunctivitis }\end{array}$ \\
\hline & GT-09 (20) & 1 & $\begin{array}{l}28 \text { days single dose safety trial } \\
\text { conducted outside the grass } \\
\text { pollen season to confirm the } \\
\text { safety of Grass allergen tablet } \\
\text { in children aged } 5-12 \text { years. }\end{array}$ & 75,000 placebo & $\begin{array}{l}30 \text { children aged } \\
5-12 \text { years with } \\
\text { grass pollen-induced } \\
\text { rhinoconjunctivitis } \\
\text { (with/without } \\
\text { asthma) }\end{array}$ \\
\hline & GT-10 & Illb & $\begin{array}{l}\text { Compliance and safety trial. } \\
\text { Duration of treatment: 6-12 } \\
\text { weeks prior to and then } \\
\text { during the grass pollen season } \\
2006 \text {. Primary objective:To } \\
\text { evaluate if subject compliance } \\
\text { of once daily dosing with } \\
\text { grass allergen tablet can be } \\
\text { increased by providing subjects } \\
\text { with a compliance device. }\end{array}$ & 75,000 placebo & $\begin{array}{l}460 \text { adult subjects } \\
\text { with grass } \\
\text { pollen-induced allergic } \\
\text { rhinoconjunctivitis }\end{array}$ \\
\hline & GT-II (20) & 1 & $\begin{array}{l}28 \text { days single dose safety trial } \\
\text { conducted outside the grass } \\
\text { pollen season to confirm the } \\
\text { safety of grass allergen tablet } \\
\text { in children aged } 5-12 \text { years. }\end{array}$ & 75,000 placebo & $\begin{array}{l}30 \text { children aged } \\
5-12 \text { years with } \\
\text { grass pollen-induced } \\
\text { rhinoconjunctivitis } \\
\text { (with/without } \\
\text { asthma) }\end{array}$ \\
\hline
\end{tabular}


Table I (Continued)

\begin{tabular}{|c|c|c|c|c|c|}
\hline & Trial ID & Phase & Trial objective/design & Doses tested SQ-T & Subjects \\
\hline \multirow[t]{3}{*}{ Ongoing trials } & GT-08 (extension) & III & $\begin{array}{l}\text { Long-term efficacy and safety } \\
\text { trial including a total of } 3 \text { years } \\
\text { of treatment (2005-2007) } \\
\text { and } 2 \text { years of follow-up } \\
\text { (2008-2009). }\end{array}$ & 75,000 placebo & $\begin{array}{l}287 \text { subjects with } \\
\text { seasonal grass } \\
\text { pollen-induced } \\
\text { rhinoconjunctivitis } \\
\text { (representative } \\
\text { subset of the subjects } \\
\text { included in the } \\
\text { original trial) }\end{array}$ \\
\hline & GT- 12 & III & $\begin{array}{l}\text { Efficacy and safety trial } \\
\text { in children ( } 5-16 \text { years). } \\
\text { Duration of treatment: at least } \\
16 \text { weeks prior to and then } \\
\text { during the grass pollen season } \\
2007 .\end{array}$ & 75,000 placebo & $\begin{array}{l}253 \text { children aged } \\
5-16 \text { years with } \\
\text { grass pollen-induced } \\
\text { rhinoconjunctivitis } \\
\text { (with/without asthma) }\end{array}$ \\
\hline & GT-I4 & III & $\begin{array}{l}\text { Efficacy and safety trial in an } \\
\text { adult US population. Duration } \\
\text { of treatment: } 8-16 \text { weeks } \\
\text { prior to and then during the } \\
\text { grass pollen season } 2007 .\end{array}$ & 75,000 placebo & $\begin{array}{l}320 \text { subjects with } \\
\text { seasonal grass } \\
\text { pollen-induced } \\
\text { rhinoconjunctivitis } \\
\text { (with/without asthma) }\end{array}$ \\
\hline
\end{tabular}

oral paraesthesia, eye pruritus, conjunctivitis, cough, asthma, pharyngitis, rhinorrhoea, nasal congestion, rhinitis throat tightness, pruritus, and fatigue. As a precautionary action the first tablet is administered in the clinic under medical supervison.

Grazax is contraindicated in the case of hypersensitivity to any of the excipients in the oral lyophilisate (tablet); in the case of malignancy or systemic diseases affecting the immune system; in case of inflammatory conditions in the oral cavity with severe symptoms such as oral lichen planus with ulcerations or severe oral mycosis; and in patients with uncontrolled or severe asthma $\left(\mathrm{FEV}_{1}<70 \%\right.$ of predicted value after adequate pharmacologic treatment).

Trials in the pediatric population have also been performed (Ibanez et al 2007). Grazax was well tolerated in children, and further clinical investigations of the efficacy and safety in children have shown corresponding effects to the results from the trials in adults which led to the European marketing approval in 2006.

Grazax has been demonstrated to be efficacious and well tolerated as home treatment and this treatment concept might allow immunotherapy treatment for a broader population including subjects not having easy access to specialists in immunotherapy and subjects who have been reluctant to undergo injection immunotherapy.

\section{Disclosures}

The authors have no conflicts of interest to disclose.

\section{References}

Andersson K, Lidholm J. 2003. Characteristics and immunobiology of grass pollen allergens. Int Arch Allergy Immunol, 130:87-107.

Bagnasco M, Altrinetti V, Pesce G, et al. 2005. Pharmacokinetics of Der p 2 allergen and derived monomeric allergoid in allergic volunteers. Int Arch Allergy Immunol, 138:197-202.

Bagnasco M, Morbelli S, Altrinetti V, et al. 2003. Allergen biodistribution in humans. Chem Immunol Allergy, 82:33-43.

Bauchau V, Durham SR. 2004. Prevalence and rate of diagnosis of allergic rhinitis in Europe. Eur Respir J, 24:758-64.

Bousquet J, Lockey RF, Malling HJ. 1998. WHO Position Paper. Allergen immunotherapy: Therapeutic vaccines for allergic diseases. Allergy, 53:1-42.

Calderon M, Essendrop M. 2006. Specific immunotherapy with high dose SQ standardised grass allergen tablets was safe and well tolerated. J Investig Allergol Clin Immunol, 16:338-44.

Calderon MA, Birk AO, Andersen JS, et al. SR. 2007. Prolonged preseasonal treatment phase with Grazax sublingual immunotherapy increases clinical efficacy. Allergy, 62:958-61.

Canonica GW, Baena-Cagnani CE, Bousquet J, et al. 2007. Recommendations for standardization of clinical trials with Allergen Specific Immunotherapy for Respiratory allergy. A statement of the World Allergy Organization (WAO) taskforce. Allergy, 62:317-24.

Dahl R, Andersen PS, Chivato T, et al. 2004. National prevalence of respiratory allergic disorders. Respir Med, 98:398-403.

Dahl R, Kapp A, Colombo G, et al. 2008. Sublingual grass allergen tablet immunotherapy provides sustained clinical benefit with progressive immunologic changes over 2 years. J Allergy Clin Immunol, 121:512-8.

Dahl R, Kapp A, Golombo G, et al. 2006. Efficacy and safety of sublingual immunotherapy with grass allergen tablet for seasonal allergic rhinoconjunctivitis. J Allergy Clin Immunol, 118:434-40.

Dahl R, Stender A, Rak S. 2006. Specific immunotherapy with SQ standardized grass allergen tablets in asthmatics with rhino-conjunctivitis. Allergy, 61:185-90.

Durham SR, Riis B. 2007. Grass allergen tablet immunotherapy relieves individual seasonal eye and nasal symptoms, including nasal blockage. Allergy, 62:954-7. 
Durham SR, Yang WH, Pedersen MR, et al. 2006. Sublingual immunotherapy with once-daily grass allergen tablets: a randomized controlled trial in seasonal allergic rhinoconjunctivitis. J Allergy Clin Immunol, 117:802-09.

Frew AJ, Powell RJ, Corrigan CJ, et al. 2006. Efficacy and safety of specific immunotherapy with SQ allergen extract in treatment-resistant seasonal allergic rhinoconjunctivitis. J Allergy Clin Immunol, 117:319-25.

Ibanez MD, Kaiser F, Knecht R, et al. 2007. Safety of specific sublingual immunotherapy with SQ standardized grass allergen tablets in children. Pediatr Allergy Immunol, 18:516-22.

Juniper EF, Guyatt GH. 1991. Development and testing of a new measure of health status for clinical trials in rhinoconjunctivitis. Clin Exp Allergy, 21:77-83.

Kleine-Tebbe J, Ribel M, Herold DA. 2006. Safety of a SQ-standardised grass allergen tablet for sublingual immunotherapy: a randomized, placebo-controlled trial. Allergy, 61:181-4.

Linneberg A, Nielsen NH, Madsen F, et al. 2000. Increasing prevalence of specific IgE to aeroallergens in an adult population: two cross-sectional surveys 8 years apart: the Copenhagen Allergy Study. J Allergy Clin Immunol, 106:247-52.
Malling H-J, Lund L, Ipsen H, et al. 2006. Safety and immunological changes during specific sublingual immunotherapy with SQ standardized grass allergen tablets. Journal Investig Allergol Clin Immunol, 16:162-8.

Moingeon P, Batard T, Fadel R, et al. 2006. Immune mechanisms of allergen-specific sublingual immunotherapy. Allergy, 61:151-65.

Rak S, Yang WH, Pedersen MR, et al. 2007. Once-daily sublingual allergen-specific immunotherapy improves quality of life in patients with grass pollen-induced allergic rhinoconjunctivitis: a double-blind, randomised study. Qual Life Res, 16:191-201.

Senel S, Kremer M, Nagy K, et al. 2001. Delivery of bioactive peptides and proteins across oral (buccal) mucosa. Curr Pharm Biotechnol, 2:175-86.

Weber RW. 2005. Cross-reactivity of pollen allergens: recommendations for immunotherapy vaccines. Curr Opin Allergy Clin Immunol, 5:563-9.

White P, Smith H, Baker N, et al. 1998. Symptom control in patients with hay fever in UK general practice: how well are we doing and is there a need for allergen immunotherapy? Clin Exp Allergy, 28:266-70. 